\title{
PRE-SERVICE TEACHERS PERFORMANCE IN IMPLEMENTING TEACHING METHODS AT TEFL CLASS
}

\author{
Maulina ${ }^{1}$, Tri Indah Rusli ${ }^{2}$ \\ ${ }^{1}$ English Lecturer at Muhammadiyah University of Kendari, Indonesia \\ Corresponding e-mail: lina821431@yahoo.com \\ ${ }^{2}$ English Lecturer at Muhammadiyah University of Kendari, Indonesia \\ Corresponding e-mail: Indahrusli1@ gmail.com \\ Muhammadiyah University of Kendari, Jln KH Ahmad Dahlan No. 10, Kendari, Indonesia
}

\begin{abstract}
This study aimed to describe the implementation of microteaching activity by preservice teachers in TEFL 2 class as well as to get an overview of the problems faced during microteaching so that they are able to improve the competence of teaching English later in both schools and other educational institutions. In this study, the method used was descriptive qualitative. The subject of the study were taken purposively by considering the achievement gained in previous subject namely in TEFL I class they reached the average value of 90 out of 100 with the number of subjects four (4) pre-service teachers. Data were collected through observation using video recording and field note as well as semi structuredinterview. Aspects to be analyzed were methods used from opening, main, and closing activities by considering the characteristics of the method applied. The results of this study showed that Grammar Translation Method (GTM) and AudioLingual Method (ALM) became a method preference during the microteaching. Pre-service teachers showed no hesitation and well prepared in applying the methods. Translation activities, dialogue memorization, repetition technique, word pair technique, and game grammar technique were occurred. Problems faced were the gap between the theories and the practice of teaching methods such as lack of skills in facial and body expression, classroom management, and stresses with noises from classmates as the students.
\end{abstract}

Keywords: Microteaching, TEFL 2, grammar translation method, audio-lingual method, preservice teachers

\section{INTRODUCTION}

It has been a global issue in English teaching classroom at university in Indonesia that preservice teachers (PSTs) at English education study program have to master in mind and action about kinds of teaching methodologies during practicum courses like TEFL 2 (Teaching as a Foreign Language 2) subject enrolled in order to better improve their competence in teaching to be a real future teacher either at schools or at other educational institutions. Over decades, the implementation of English teaching methodologies by PSTs have shown more important roles in English as a foreign language (EFL) classroom (Kizilaslan, 2012; Chien, 2014; Velthuis, Fisser, \& Pieters ;2017). Practicum experiences in educational program is designed to improve the teacher candidates' practical teaching skills under the guidance of a lecturer that is important by transferring course learning which is mostly theoretical in nature of teaching considering that the classmates as students and conditions are real. Akcan \& Tatar (2010) state that 
university supervisors in mentoring student teachers help them to reflect their performance more critically during their post-lesson conferences. Similarly, a number of researchers argue the important role that teaching practices by PSTs in English classroom. During the teaching simulation program, students find themselves studying effectively with instructional method designed and fell satisfied with from that program (Ozdilek \& Oncu, 2014). In addition, Koc \& Ilya (2016) point out that by providing feedback during micro-teaching, it enables PSTs to develop their skills in teaching practice ( $\mathrm{p}, 428)$.

Teaching practice is an academic duty in which PSTs put theory of English teaching methodologies into practice. Teaching practice, in Indonesia context, is one amongst curricular activities that must be undertaken by EFL PSTs before they graduate from the university. Being a compulsory subject, teaching practice in TEFL II class enhance the PSTs to acquire knowledge of teaching, value, and good behavior for a successful future teaching.

At present time, it has become the state of art paid to the way of PSTs teaching English especially in the teaching practicum in TEFL II class. PSTs acquire English teaching methods theories like Grammar Translation Method (GTM), Audio Lingual Method (ALM), direct method, silent way, Total Physical Response (TPR), Community Language Learning (CLL), and suggestopedia studied in previous class i.e. TEFL I subject with the goal is to contextualize PSTs teaching in nature. As an effort to establish English teaching competence, however, the theories of teaching mastery are sometimes found difficult in the implementation.

In addition, learning teaching is more effective when teaching practices occur in the appropriate context based on the characteristic of teaching methods applied. The current research has been focusing on the English teaching methods (West \& Vespoor, 2016; Prastyo, 2015; Howath \& Smith, 2014; Assalahi, 2013; and Chaves \& Hernández, 2012). In addition to its importance the English teaching methods delivered, PSTs can develop their own teaching practices, it may more effectively provide creative thinking, motivation, socialization, and professional development. Although research has reported the advantages of English teaching methods in many aspects, there is not any research, few if any, investigating the teaching flow and challenges in PSTs' teaching practices in TEFL 2 classroom with English teaching method experts. The following research questions were investigated in this study:

1. How are the interactions between PSTs and the students?

2. What methods do the PSTs apply in teaching practice?

3. What are the obstacles faced during the teaching practices?

\section{METHODOLOGY}

\section{Research Design}

This study was conducted by using descriptive qualitative research design with the purpose was to capture the complexities of the teaching practicum process in TEFL II class and experiences of the PSTs had since it would be possible to obtain in-depth and rich data.

\section{Participants}

The subjects in this study were third-year students of English education study program at Muhammadiyah University of Kendari. The subject was taken purposively. It was there were 4 PSTs who got mark A in TEFL I class chosen to perform teaching practices. Before the teaching practicum began, the researcher asked sought their willingness to participate in this study. The subjects programmed TEFL II class to apply theories 
of English teaching methodologies they have learnt in TEFL I. These subjects are compulsory taken before the PSTs experience field teaching at schools.

\section{Data Collection}

In this study, the researcher used three methods in collecting data namely, observation using video recording and field note as well as semi structured-interview. Before interviewing the subjects, the researcher conducted some observation while having field notes when the PSTs delivered their lessons. The observation is beneficial for the researcher who expects to capture the teaching and learning process from the opening, main, and closing activities. In the observation part, the researcher directly observed each participant using video recorder in hand and took some notes when the lesson was delivered. The participants were briefed before the observation and the interviews began. This purpose was to prepare participant mentality and confidence during the research which it helped achieve the goal of the current study. To do the observation, some questions noticed and described as follows:

a. How is the PSTs' interaction with the learners during the teaching practicum?

b. What methods are used?

c. What are factors disturbing the PSTs in teaching practicum?

The researcher also implemented an interview session after the PSTs conducting their teaching practicum with the purpose was to find out some obstacle solutions for themselves and implemented the new solutions for further lessons. The interview each lasted for about 35-40 minutes and the results were transcribed verbatim.

\section{Data Analysis}

In analyzing the data, the researcher followed Rubin \& Rubin (2005) steps. Firstly, she managed the data from the observations and interviews by categorizing the data based on the group such as PSTs-learners interaction, teaching methods, and teaching obstacles. Secondly, the researcher divided excerpts based on the categories and described them based on the utterances. Thirdly, she analyzed the utterances deeply and carefully in order to meet deep understanding of the data. Lastly, she summed up a conclusion of the analysis.

\section{FINDINGS AND DISCUSSION}

\section{Findings}

The findings of this current study were reported separately in three different sessions, PSTs and students interactions, methods used, teaching obstacles, as well as they were followed by discussion.

\section{Pre-service teachers-students interaction}

The first part of the research deals with the situation in the classroom which PSTs handled the class from beginning, main, and ending the lesson. Before delivering the lesson, PSTs had the teaching preparation like lesson plan, materials such as handout as well as technical and non-technical media. PSTs did such harmonious interactions with the students during the practicum period. These interactions appeared to represent the themes observed as follows:

a. PSTs interacted with the whole class.

b. PSTs interacted with a group, pair, and individual student.

c. Students interacted with each other: in groups, in pairs, as individuals or as a class.

d. Students worked with materials or aids and attempted task individually, in pairs, and in groups.

The PSTs sometimes interacted with the class as a whole at other times with groups in the class. As an important component of 
interactions, classroom management was handled fairly well during the lessons. PSTs sometimes asked questions and were responded by the students directly as well as they were followed by direct and indirect feedback. The way PSTs and students behaved and interacted during the lessons were sometimes organized and controlled well. In controlling the class, PSTs found it a bit overwhelmed in some occasions.

\section{PST1: I found it a little bit hard in managing} my classroom... especially in managing the students. There were so crowded here and there when I was explaining the lesson instructions.

In line with PST1, PST4 showed the same experience in the classroom management. Frustrating was caused by the failure in controlling the students in some part of the class sessions.

PST4: It seemed a big deal for me when I delivered the lesson in main part. Students showed no respect when I am showing one of English expression on the slide... they were talking to their friend who was sitting next to him. Therefore, I repeated the explanation more than three times.

However, PTS2 and PTS3 responded that they felt that they had done a fluent teaching performance without any difficulties in terms of managing the classroom.

PTS2 \&PTS3: During the teaching practices, I was thinking that I had done it well with no any burden in controlling my students. I presumed that they were easy to be handled from the start, main, and end the class.

Based on the whole observation to all PTSs observed, the researcher pointed out that the PTSs' capabilities in doing the interactions with students in relation to classroom management were varied in terms of materials delivered, classroom atmosphere, and students' motivation.

\section{Teaching Methodology Preference}

In teaching practices, there were three phases in common delivered by PTSs, they were beginning, main, and ending the lesson. Lesson plan, materials, teaching media, and teaching methods have been previously prepared and chosen. The teaching methods that performed by the fourth participants were varied.

The first, the third, and the fourth participant (PTS1, PTS3, PTS4) preferred implementing Grammar Translation Method (GTM). They used more first language (Indonesian), with little active use of target language. They also put much of the vocabulary list on the whiteboard during her teaching performance. They were really responsive in applying GTM that they felt it was suit with the students and classroom situations. The explicit grammar teaching occurred in the data as the core of the teaching method.

PTS1: when I am about to teach, I prepare all vocabularies relating to the topic on the lesson. And when I teach past tense, I write on the whiteboard the rule for example I put pronouns with blue underlined... after that I put verb with black underlined... and the object complementary with red underlined.

In addition, the PTS1, PTS3, and PTS4, in some parts, mix their language (Indonesian-English or English-Indonesian). The use of first language (L1) was reported to be used in giving instructions to students in order to transfer the meaning of the 
grammar and the meaning of the English words in the text given.

PTS3: In explaining the material, I mix Indonesian and English... because I say 'recall' in English but my students do not understand... for this reason I have to use Indonesian language.

PTS1 \& PTS4: in explaining the English rules, I use Indonesian to explain, which the patterns for a simple sentence both Indonesian and English simple sentences are the same.

PTS1, PTS3, and PTS4 started with illustration of grammar rules on the whiteboard and supported with the small handout given to each student, use of colors, use of Indonesian language, recognition and substitution drills, repetition drills, word pair technique, game grammar technique, and repetition of chunk of the language were occurred in the teaching practices.

PTS2, however, preferred using Audio Lingual Method (ALM) in her teaching performance.

\section{Teaching Obstacles}

This study revealed that problems or obstacles were faced by PTSs in implementing the English methods before, during, and after the lesson. The overall problems observed were stated as follows:

a. Problems in expressing enthusiastic performance because of facial and body expressions difficulty.

b. Problems in classroom management.

\section{Discussion}

This study aimed to describe the microteaching performances as experienced

Fakultas Keguruan dan Ilmu Pendidikan Universitas Bosowa Makassar by the PSTs who programmed TEFL II subject in English Education Study Program at Muhammadiyah University of Kendari. The results show that the obstacles faced during the microteaching were related to teaching methods, classroom management, learning resources, teaching aids or media both technical and non-technical, PSTs' English skills, choice of language use, PSTs' motivation, and evaluation technique. Regarding the challenge on classroom management, this study reveals that the preservice EFL teachers faced some difficulties in controlling over the learners (classmates) in the classroom. The factors that influenced such challenge were due to noises produced by the learners during the lesson, learners' boredom that emerged from the beginning of the lesson, unexpected chats among learners and learners' lack of attention and respect toward the teacher. Moreover, some preservice EFL teachers could not acknowledge the way of how to start the lesson, how to keep the class under control, and how to end the lesson. The PSTs believed that what they learned from a microteaching was much different from what they experienced in microteaching at TEFL class II. Consequently, they were stressed due to the problems related to the classroom management. In line with that, the researchers (Merç \& Subaşi, 2015) who did a research on pre-service teachers' challenges in a teaching practicum also revealed similar factors which influenced the classroom management. It resulted that learners' noises, laziness, lack of interest, unexpected chat, lack of respect and attention caused a problem toward the pre-service teachers' classroom management. The research by Akin and Yildirim (2016) is more concerned with determining strategies of keeping up successful classroom management rather than finding out causes of the obstacles. In the study, they summed up that successful classroom management can achieved by promoting time management, behavior 
management, and relationship management which rely on practical procedures of teaching. Interestingly, EFL teachers can minimize their stress or anxiety about classroom atmosphere by setting up good plans and control over time effectively (Aydin, 2016). In addition, PSTs have to try various ways including setting up teaching procedures, asking the learners to follow the instructions as planned, and expand communicative interaction between the teacher and the learners during the lesson (Emmer \& Stough, 2001).

The results of this study indicate that the PSTs faced some obstacles in terms of learning materials and learning resources including unavailability of updated learning resources, grammar-based learning resources, and unavailability of contextual and communicative learning materials. More preservice EFL teachers browsed materials or download available materials from the internet. Availability of updated or authentic materials has become a comprehensive issue among the EFL teachers who put their concern with introducing real world to their EFL learners. Cunningsworth (1984) points out that selection of learning materials should reflect on natural contexts within with English is used and the materials have to be balanced with learners' "age, level of education, social attitudes, the intellectual ability and level of emotional maturity" (p. 71). Similarly, Kalin (2004) also stresses on the importance of teachers' and learners' attributes such as basic knowledge, age, achievement, intelligence, and participation. This implies that learning materials should to be selected based on the need of learners and this also indicates that real-world learning materials are paramount compared to those which focus on grammar-based learning resources. However, a problem that appears in selecting learning materials is suitability of the materials for learners with either high or low knowledge as it must be a difficult task for a teacher to design and compile the materials that are suitable for both categories of learners. In this case, needs analysis is highly acceptable to ensure that the learners obtain fair teaching and learning treatment, and that the materials fit with learners' knowledge. Brown (1995) defines that needs analysis "serves as the basis for developing tests, materials, teaching activities, and evaluation strategies, as well as for reevaluating the precision accuracy of the original needs assessment" (p. 35). It proves that determining learners' background knowledge and needs before starting a lesson is an effective solution which enables the PSTs to create suitable learning materials for their learners.

Regarding the obstacles in terms of delivery of instruction, this current study shows that PSTs got difficulty in implementing a method of teaching and assessing the learners as prepared in a lesson plan. They were mostly pushed to replace their plans and demotivated as the theories they learned were not similar to those in the field of teaching practicum. These problems did not allow the pre-service EFL teachers to manage their EFL classrooms properly. Moreover, the use of English as the language of instruction could not be successfully fulfilled as the learners had low ability in English. Teachers' language has an effect on learners' thoughts that can be used as a tool for communication in different classroom situations (Rau, 2016). The obstacles are in line with the findings of a study by Gan (2013) which revealed that English teachers attending a teaching practicum were faced with several obstacles in terms of how theories and practices of teaching methods were relevant, what language they should use in the EFL classrooms, and how they controlled over the learners. The gap between theory and practice as viewed by the PSTs is influenced by learners' background knowledge on teaching concept, microteaching, and field of teaching practicum (Cheng, Tang, \& Cheng, 2010). The results of this study also reveal that the 
EFL learners were lack of motivation to learn English and follow the lessons. Learners' lack of motivation, interest, and attention demotivate the pre-service EFL teachers (Han, \& Mahzoun, 2017). This also causes the pre-service EFL teachers to modify their strategies in order to achieve goals. Similarly, research findings of Yunus, Hashim, and Mahamod (2010) show that pre-service teachers used variety of teaching methods suitable with the learners' motivation, interest, and behavior.

\section{CONCLUSION}

Based on the focus of this current study, it is concluded that Grammar Translation Method (GTM) and AudioLingual Method (ALM) became a method preference during the microteaching. Preservice teachers showed no hesitation and well prepared in applying the methods. Translation activities, dialogue memorization, repetition technique, word pair technique, and game grammar technique were occurred. Problems faced were the gap between the theories and the practice of teaching methods such as lack of skills in facial and body expression, classroom management, and stresses with noises from classmates as the students. The obstacles experienced by the PSTs in Microteaching at TEFL class II was the classroom management which proves that it was not an easy task for PSTs to manage their classrooms and control over their learners as highlighted in a lesson plan. Managing EFL classrooms was influenced by learners' noises, chats, and lack of attention. In addition, the EFL materials can be handbooks, updated books or articles, and authentic materials. Moreover, the absence of the use of advanced technology as teaching media both technical and non-technical one was a main factor of low motivation and enthusiasm. Unavailability of updated learning materials and technological instructional media had a bad impact on successful teaching and learning. The next challenge is that lack of understanding and insufficient background knowledge which became the factors that disturb the PSTs to implement a teaching method. Selection of teaching method was also influenced by English skills and abilities that the PSTs perform. Prepared and expected teaching method can be replaced or modified when the classroom atmosphere was not suitable with the lesson plan. Similarly, evaluation technique such as a test has to be designed based on learners' understanding and comprehension toward the lesson materials. Insisting on implementing a method discourages student participants' motivation, interest, and attention. As a part of the challenge, language chosen by the PSTs as an instructing language decreases student participants' enthusiasm to keep attending a microteaching session. Therefore, the PSTs at Microteaching session for TEFL Class II have to master the theory of teaching methodologies in order to overcome the gap between the theories and the practice before enrolling the practices that they can be able to pursue the real microteaching in the school field and other educational institutions both public and private institutions. Theory of teaching methodologies of English as a foreign language perform in microteaching model during class hour and pre-service teacher gets feedback from the lecturer to be further improved in the next microteaching occasion. In sum, mastering approaches in teaching practice or simulation implemented by pre-service teachers in English education study program in Indonesia context which have symbolized in foreign language (FL) teaching have been obligated in order to establish the competence to be future real FL teachers. There has been much attention on pre-service teachers experiencing a teaching simulation in the classroom, but few consider the flow of teaching simulation performance and obstacles faced during the teaching. 


\section{ACKNOWLEDGEMENTS}

This research was supported by Ministry of Research and Higher Education under the scheme of beginner lecturer research in 2017. We thank the people of research institutions and community service (LPPM) of Universitas Muhammadiyah Kendari who provided insight and expertise that greatly assisted the research in the form of a wellmanagement and support for us to deepen insight on research.

\section{REFERENCE}

Akcan, S \& Tatar, S. (2010) An investigation of the nature of feedback given to pre- service English teachers during their practice teaching experience, Teacher Development, 14(2), 153-172, DOI: 10.1080/13664530.2010.494495

Assalahi, H. (2013). Why is the grammar translation method still alive in the Arab world? Teacher's beliefs and its implications for EFL teacher education, Theory and Practice in Language Studies, 3(4), 589-599.

Chaves, O \& Hernández, F. (2012). EFL teaching methodologies in Cali. Profile, 15(1), 61-80.

Chien, C-W. (2014) Pre-Service elementary school English teachers' learning and reflection through simulated teaching practice and oral interviews, Reflective Practice, 15(6), 821-835, DOI: 10.1080/14623943.2014.944139

Howath, A.P.R \& Smith, R. (2014). The history of teaching English as a foreign language, from a British and European perspective. Language and History, 57(1), 75-95.

Kizilaslan, I. (2012) Teaching in rural Turkey: pre-service teacher perspectives, European Journal of
Teacher Education, 35(2), 243-254, DOI:

10.1080/02619768.2011.643394

Koc, B \& Ilya, A. (2016). Exploring preservice teachers' perceptions and actual practices of giving feedback in micro-teaching, Procedia Social and Behavioral Sciences. 232, $421 \quad-426 . \quad$ DOI: 10.1016/j.sbspro.2016.10.058

Ozdilek, Z \& Oncu, S. (2014). Pre-service teachers' views on simulations in Education: an interdisciplinary instructional development experience. Procedia - Social and Behavioral Sciences 141, 11561160.

Prastyo, H. (2015). The implementation of Grammar Translation Method (GTM) and Communicative Language Teaching (CLT) in teaching integrated English. Indonesian EFL Journal, 1(2), 170182.

Rubin, H.J.,\& Rubin, I.S. (2005). Qualitative interviewing: The art of hearing data. Thousand Oaks, CA: Sage.

Velthuis, C., Fisser, P., \& Pieters, J. (2017) Teacher Training and Pre-service Primary Teachers' Self-Efficacy for Science Teaching, Journal of Science Teacher Education, 25(4), 445-464, DOI: 10.1007/s10972013-9363-y

West, L \& Verspoor, M. (2016). An impression of foreign language teaching approaches in the Netherlands. Levende Talen Tijdschrift Jaargang 17 , nummer 4 , 